\title{
Reproduction of the greater bulldog bat Noctilio leporinus (Chiroptera: Noctilionidae) in a mangrove area in southern Brazil
}

\author{
Marcelo Oscar Bordignon ${ }^{1,3}$ \& Adriana de Oliveira França ${ }^{2}$ \\ ${ }^{1}$ Laboratório de Zoologia, Universidade Federal de Mato Grosso do Sul - UFMS, \\ Cidade Universitária, CEP 79070-900, Campo Grande, MS, Brasil. www-nt.ufms.br \\ ${ }^{2}$ Laboratório de Parasitologia Humana, Centro de Ciências Biológicas e da Saúde, \\ Universidade Federal de Mato Grosso do Sul-UFMS, Cidade Universitária, CEP 79070-900, \\ Campo Grande, MS, Brasil.www-nt.ufms.br \\ ${ }^{3}$ Corresponding author: Marcelo Oscar Bordignon, e-mail: marcelo.bordignon@ufms.br
}

BORDIGNON, M.O. \& FRANÇA, A.O. Reproduction of the greater bulldog bat Noctilio leporinus (Chiroptera: Noctilionidae) in a mangrove area in southern Brazil. Biota Neotrop. 12(4): http://www. biotaneotropica.org.br/v12n4/en/abstract?article+bn01412042012

\begin{abstract}
The reproductive pattern of the greater bulldog bat (Noctilio leporinus) was studied in southern Brazil from January to December 1999. The morphological characteristics of their reproductive organs were recorded monthly, through histological analysis of testes and ovaries. Those data were correlated with forearm size and body mass, as well as with external reproductive characteristics. The diameter of the seminiferous tubule increased proportionately to testis mass and body weight, and larger males had greater testis mass. Sexually mature males were recorded throughout the year. Ovary histology revealed that females ovulate between July and December. Lactating females were recorded in nearly every month of the year. Noctilio leporinus has a bimodal polyestrous pattern, with an increase in the recruitment of juveniles between January and May.

Keywords: aquatic systems, Neotropics, reproductive cycle, seminiferous tubules, testis mass.
\end{abstract}

BORDIGNON, M.O. \& FRANÇA, A.O. Reprodução do morcego-pescador Noctilio leporinus (Chiroptera: Noctilionidae) em uma área de manguezal no Sul do Brasil. Biota Neotrop. 12(4): http://www.biotaneotropica. org.br/v12n4/pt/abstract?article+bn01412042012

Resumo: Entre janeiro e dezembro de 1999 foi estudado o padrão reprodutivo do morcego-pescador (Noctilio leporinus) no sul do Brasil. Foram registradas mensalmente as características morfológicas de seus órgãos reprodutivos, através da análise histológica de testículos e ovários. Estes dados foram correlacionados com o tamanho do antebraço e a massa corporal, bem como as características reprodutivas externas. O diâmetro dos túbulos seminíferos dos machos aumentou proporcionalmente à massa dos testículos e à massa corporal, e machos maiores também apresentaram maior massa de testículos. Machos sexualmente maduros foram registrados ao longo de todo o ano. A histologia dos ovários revelou que as fêmeas ovulam entre julho e dezembro. Fêmeas em lactação foram registradas em quase todos os meses do ano. Este estudo revelou que Noctilio leporinus tem um padrão reprodutivo poliestral bimodal, com um maior recrutamento de jovens entre janeiro e maio.

Palavras-chave: sistemas aquáticos, Neotrópico, ciclo reprodutivo, túbulos seminíferos, massa do testículo. 


\section{Introduction}

Bats have the most varied mating system of all mammals (Feldhamer et al. 1999). Species from temperate climates are generally monoestrous, but the majority of tropical species are polyestrous (Nowak 1994). In bat species such as Tonatia bidens and Artibeus lituratus, in which females have two or more breeding cycles per year (Esbérard \& Bergallo 2004, Ortêncio Filho et al. 2007), males may remain sexually active longer and, in some cases, throughout the entire year (Duarte \& Talamoni 2010).

The greater bulldog bat, Noctilio leporinus (Linnaeus, 1758), is widely distributed throughout the Neotropics (Koopman 1982). Although this species is common, some aspects of their biology and ecology are still poorly studied. The social organization of this species is based on polygyny, in which the adult male defends a group of females, with younger males either remaining solitary or in groups far from the female shelters (Brooke 1997). In Mexico, the species was reported to mate in winter, nursing its young in the spring and summer (Hernandez et al. 1985), while in Puerto Rico copulations occurred in September and November, with births occurring only in May (Brooke 1997).

For $N$. leporinus, studies have been limited to feeding ecology (Bordignon \& França 2002), on the dimorphism in the color of the fur among males and females (Bordignon \& França 2004), and on the species feeding behavior (Schnitzler et al. 1994, Zortéa \& Aguiar 2001, Bordignon 2006a). In a semi-arid biome of northeastern Brazil a seasonal monoestrous reproductive pattern was found, with breeding synchronized to the period of greater food supply (insects and fish), which occurs in the rainy season from November to April (Willig 1985). In southern Brazil, the mating behavior of $N$. leporinus was recorded in nature by Marques \& Pacheco (1999) and the reproduction in captivity was reported by Silva et al. (2010).

Considering that none of the previously cited studies focused on internal or physiological aspects associated with the reproduction of the species, the aim of the present study was to determine the reproductive pattern of male and female $N$. leporinus in a mangrove ecosystem in the southern Atlantic Forest of Brazil, through histological characterisation of their reproductive organs (cell maturation in testes and ovaries) and external morphological characteristics (testis weight, presence of fetus, lactation).

\section{Materials and Methods}

\section{Study site}

The study was carried out in the municipality of Guaratuba, state of Paraná, on the southern coast of Brazil $\left(25^{\circ} 50^{\prime} \mathrm{S}\right.$ and $48^{\circ}$ $34^{\prime}$ W). The site is a bay with an area of $48.7 \mathrm{~km}^{2}$, depths ranging from two to $23 \mathrm{~m}$, and is located near the Serra do Mar mountains with typical Atlantic Rainforest vegetation. The bay is widely used by local communities for subsistence and sport fishing. It also serves as a nursery for many marine species, with large amounts of fingerlings (Chaves \& Vendel 1997). The climate is humid subtropical (cool winter and warm summer), with precipitation in most months and a greater volume of rainfall in summer (October to March). Annual rainfall ranges from 1250 to $2000 \mathrm{~mm}$. The monthly mean temperature ranges between 14 and $22{ }^{\circ} \mathrm{C}$, with the coldest period between June and August and the warmest between September and May. The salinity of the water rarely surpasses 30.0\% (Chaves 1995).

\section{Bat sampling and histological analysis}

Specimens were captured monthly between January and December 1999, from 6:00 PM to 6:00 AM using seven mist nets of
$2.6 \times 9 \mathrm{~m}(\mathrm{CH} 9$ model, Avinet Inc. USA) arranged perpendicularly to the margin of the bay and over the surface of the water. The nets were checked every 15 minutes. Captured bats were removed from the net, placed into a black cotton bag $(20 \times 40 \mathrm{~cm})$ and taken to the laboratory for the recording of the morphometric and biological data. Five nights of capture per month were performed totaling an effort of $9828 \mathrm{~m}^{2} . h$ throughout the year.

The specimens were placed in a recipient containing a cotton ball soaked in anesthetic ether, until sleep. This enabled handling the specimens for five to eight minutes during the recording of the biometric data. Each individual was identified with a tag and placed in a cage at a temperature of $25-32{ }^{\circ} \mathrm{C}$ until being released at the original capture site. One hundred and five individuals (54 males and 51 females) were captured and data on forearm length, body mass, sex and reproductive status were recorded. Males with visibly developed extra-abdominal testes and pregnant (determined by abdominal palpation), lactating and post-lactation (large, dark teats with no surrounding hairs) females were classified as adults. In all males $(n=54)$ total length of the right testes were measured (in mm). These measurements served as the estimate for the assessment of sexual maturation and compared to the histological data of the collected males.

Twenty-three males and 15 females were collected for the histological analysis of their reproductive organs. Bats were killed using anesthetic ether inhalation, in compliance with the norms established by the American Society of Mammalogists (Gannon \& Sikes 2007).

The right testis of each male was extracted and weighed prior to fixation for the comparison with body mass. The reproductive organs (testes and ovaries) from the right side of the body were fixed in a solution of ethanol, formaldehyde (40\%) and acetic acid at a proportion of 85:10:5 for 24 hours. The specimens were then submitted to routine histological methods with $5 \mu \mathrm{m}$ sections stained with hematoxylin-eosin (Beçak \& Paulete 1976, Rose et al. 1997).

Tissue from the region near the epididymis was examined on slides with an optical microscope at a magnification of $450 \times$. The mean seminiferous tubule diameter (20 tubules/testis) of the testis of each male was determined using only tubules with round sections. The stage of spermatogenesis and presence of spermatozoids in the seminiferous tubules were determined (Parreira \& Cardoso 1991). Only males with spermatozoids in the lumen of the tubules were considered mature. The histological sections of the ovaries were analyzed for cellular characteristics of the follicle maturation process (Graafian follicles and corpus luteum).

A correlation between the histological data of the testes (mass and seminiferous tubule diameter) and the forearm size was tested using Pearson's correlation test. A one-way analysis of variance (ANOVA) was used to compare the mean forearm length between breeding and non-breeding males, as well as the reproductive status of the animals captured in the different months.

\section{Results}

Among the fifty-one females captured during the study period about $60 \%$ were non-breeding (Figure 1). Non-breeding females were recorded from January to August, whereas pregnant females were recorded only in April, August, November and December. Lactating females were recorded throughout the year.

The number of non-breeding females recorded throughout the year was significantly different from the number of lactating (ANOVA $F=5.202 ; p=0.005$ ) and pregnant females (ANOVA $F=5.566$; $p=0.004)$. All females captured from September to December 
(spring) were either lactating or pregnant. Non pregnant females were captured between January and March (summer).

Females with a corpus luteum (post-ovulation) were only recorded between July and December (Figure 2). Females with Graafian follicles were recorded in April and May. No females with such breeding characteristics were recorded between January and March.

Among the 23 males histologically examined, nine exhibited spermatogenesis. However, those individuals were distributed among several months throughout the year (Figure 3). Based on the external

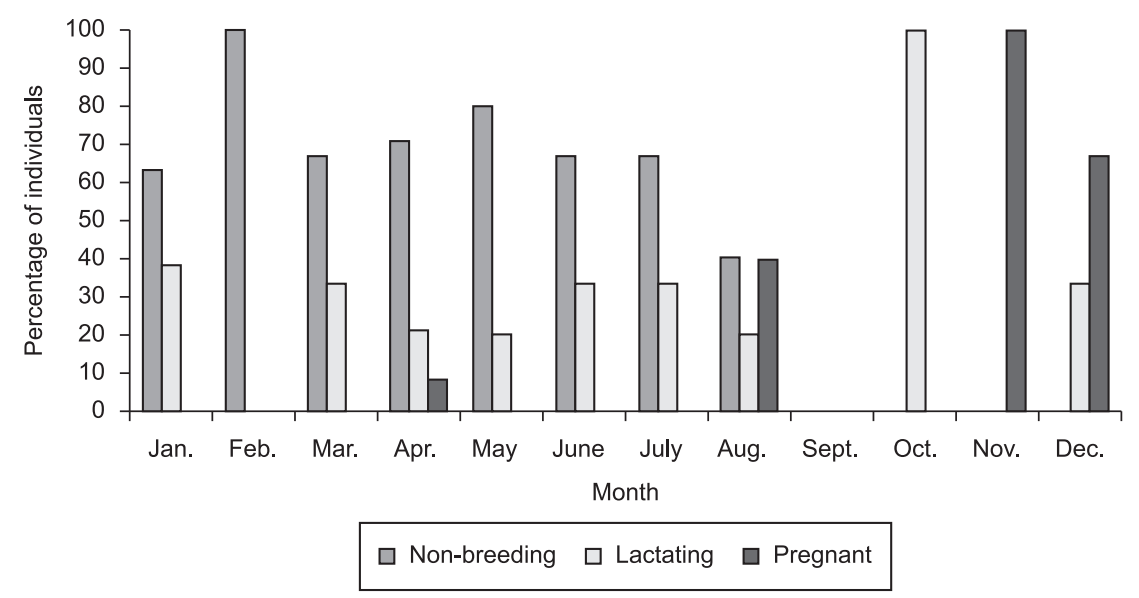

Figure 1. Reproductive pattern of female $N$. leporinus in a mangrove area of southern Brazil, based on external characteristics.

Figura 1. Padrão reprodutivo de fêmeas de $N$. leporinus em uma área de manguezal no sul do Brasil, baseado nas características reprodutivas externas.

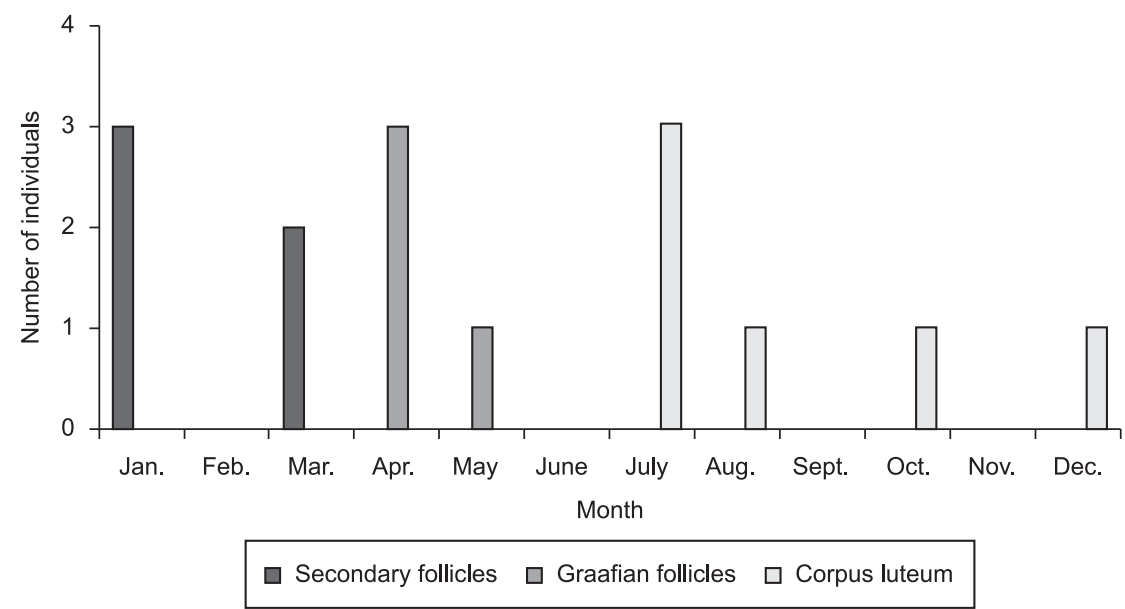

Figure 2. Reproductive pattern of female $N$. leporinus in a mangrove area of southern Brazil based on histological examination of ovaries.

Figura 2. Padrão reprodutivo de fêmeas de N. leporinus em uma área de manguezal no sul do Brasil, baseado no exame histológico dos ovários.

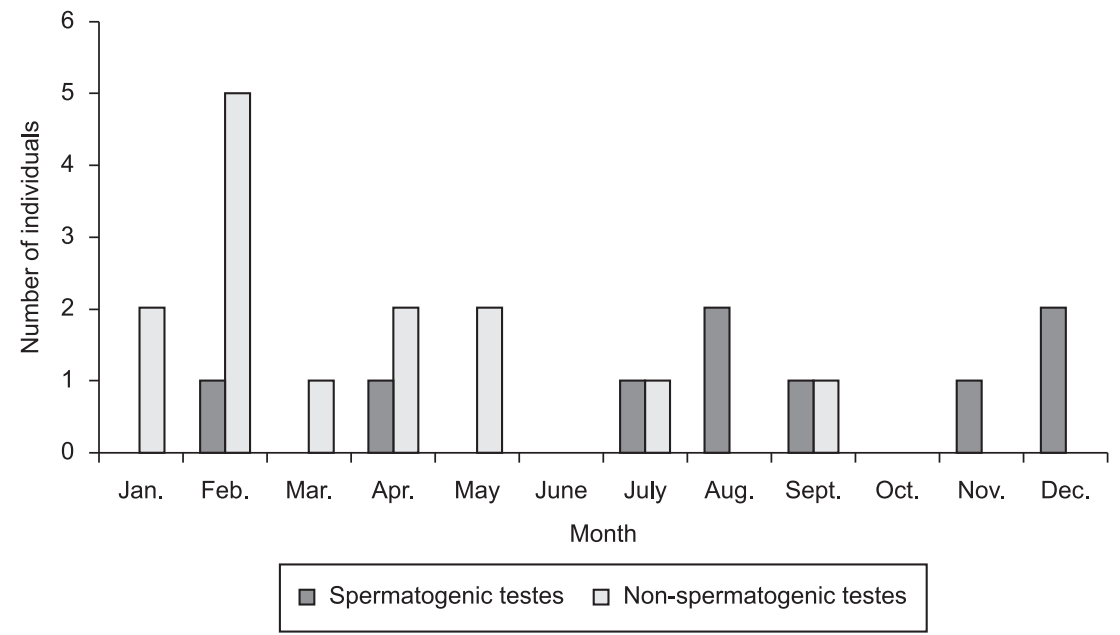

Figure 3. Reproductive pattern of male N. leporinus in a mangrove area of southern Brazil based on histological examination of testes.

Figura 3. Padrão reprodutivo de machos de $N$. leporinus em uma área de manguezal no sul do Brasil, baseado no exame histológico dos testículos. 
characteristics of the 54 males collected, breeding males (with large testes) accounted for $42 \%$ of the sample $(n=23)$. Few breeding males were recorded from January to March (Figure 4). In this same period, non-breeding males represented $27 \%$ of the total catch for the entire year. Although no non-breeding males have been recorded between October and December, there was no statistically significant difference in the distribution of breeding and non-breeding males throughout the year (ANOVA $F=1.079 ; p=0.451$ ).

There was a positive correlation between testis mass and body mass among the 23 males collected for the histological analysis (Pearson $r=0.774 ; p<0.001$ ) (Figure 5a). There was also a positive correlation between testis mass and forearm length (Pearson $r=0.643 ; p=0.001$ ) (Figure 5b).

The majority of males weighing $>90 \mathrm{~g}$ had a testis mass ranging from 1.16 to $1.46 \mathrm{~g}$. Among those weighing between 80 and $90 \mathrm{~g}$, testis mass ranged from 0.16 to $1.21 \mathrm{~g}$. For those weighing less than $80 \mathrm{~g}$, testis mass ranged from 0.09 to $0.48 \mathrm{~g}$. There was a positive correlation between mean seminiferous tubule diameter and testis mass among the 23 males submitted to histological analysis (Pearson $r=0.833 ; p<0.001$ ) (Figure 6).

In non-breeding males with a testis weight $<1.0 \mathrm{~g}(0.29+0.35$; $\mathrm{n}=17)$, the diameter of the seminiferous tubules was $<100$ $\mu \mathrm{m}(59.17+25.57)$, with no spermatozoids in the lumen. In those specimens, only spermatogonia, Sertoli cells and primary spermatocytes were observed.

In males with a testis weight $>1.0 \mathrm{~g}(1.25+0.84 ; \mathrm{n}=6)$, the diameter of the seminiferous tubules was $>100 \mu \mathrm{m}(148.70+30.15)$ and the epithelium exhibited spermatocytes in different degrees of development and spermatozoids in the lumen of the tubule, revealing that these males were sexually mature. Mean forearm length of nonbreeding males $(97.20+1.91 \mathrm{~mm} ; \mathrm{n}=6)$ was significantly lower (ANOVA $F=4.390 ; p=0.046$; Tukey $Q=2.963$; $\mathrm{p}<0.05$ ) than that of breeding males $(99.00+1.22 \mathrm{~mm} ; \mathrm{n}=17)$.

\section{Discussion}

Both the external sex characteristics and histological analysis of the testes revealed that the male greater bulldog bat is capable of mating in any season of the year. Despite living in a polygenic mating system, in which an adult male defends a group of females (harem), fecundation is determined by the fertility status of the females (Feldhamer et al. 1999).
The histological data show that the population analyzed tends to mate after the summer months, with ovulation occurring between early winter (July) and early summer (December). However, the assessment of external genital characteristics of the females showed that lactation occurs in nearly all months of the year. In captive conditions Silva et al. (2010) observed that females of this species showed synchronization of births of pups in October and November, although copulations were observed throughout the year.

We believe that the histological data obtained show just a glimpse of what may be occurring in this species mating. Probably young females start to synchronize their ovulation with other females in the group only after the first ovulation that occurs at puberty. If true, then most data on lactation obtained in our study may derive from females nursing their pups for the first time. This seems logical, since young females do not always have a hierarchy already established in the harem.

The larger number of non-breeding females compared with lactating or pregnant females in April (Figure 1) may indicate a peak recruitment of the juvenile population in this period in the study site, as there was also a high number of non-breeding or sexually immature males in February. The breeding pattern for the $N$. leporinus females in the present study was similar to the bimodal polyestrous pattern reported for other species of tropical bats (Tamsitt \& Valdivieso 1963, Reis 1989, Chaverri \& Kunz 2006, Duarte \& Talamoni 2010).

The positive correlation between testis mass and mean seminiferous tubule diameter in $N$. leporinus males was expected, as spermatogenesis was presumed to be more intense in males with heavier testes. The histological data on spermatogenic activity were similar to those described by Duarte \& Talamoni (2010) for Artibeus lituratus in southeastern Brazil. However, the mean diameter of the seminiferous tubules in $N$. leporinus was smaller in both breeding and non-breeding males than that described for $A$. lituratus in the study cited. This difference may be related to technical factors, such as the method of fixation of the organs, or the ontogeny and anatomy of the species in question. Although males considered young had underdeveloped testes, it was not possible to ascertain whether the adult males of the greater bulldog bat studied here undergo regression in the spermatogenic activity, as occurs in bats from temperate regions with strong seasonal variations in climate (Racey 1974, Entwistle et al. 1998).

The correlation between testis mass and body size (forearm and weight) indicated that some large males ( $>85 \mathrm{~g}$ ) had a low testis mass $(0.29+0.35 \mathrm{~g})$. This may be explained by the existence of a size range

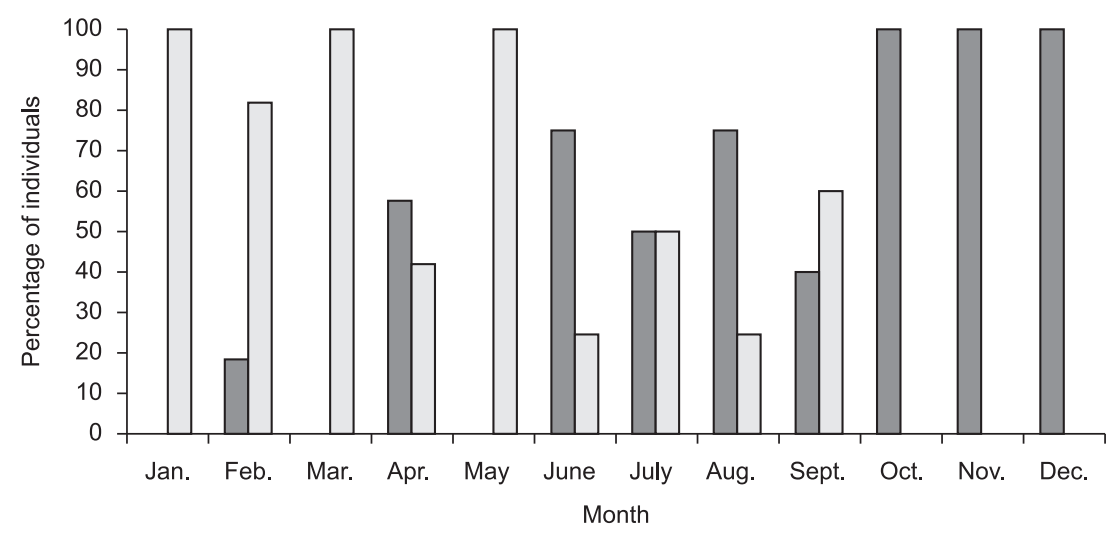

$\square$ Breeding males (large testes) $\square$ Non-breeding males (small testes)

Figure 4. Reproductive pattern of male $N$. leporinus in a mangrove area of southern Brazil based on external testis size.

Figura 4. Padrão reprodutivo de machos de $N$. leporinus em uma área de manguezal no sul do Brasil, baseado nas dimensões externas dos testículos. 

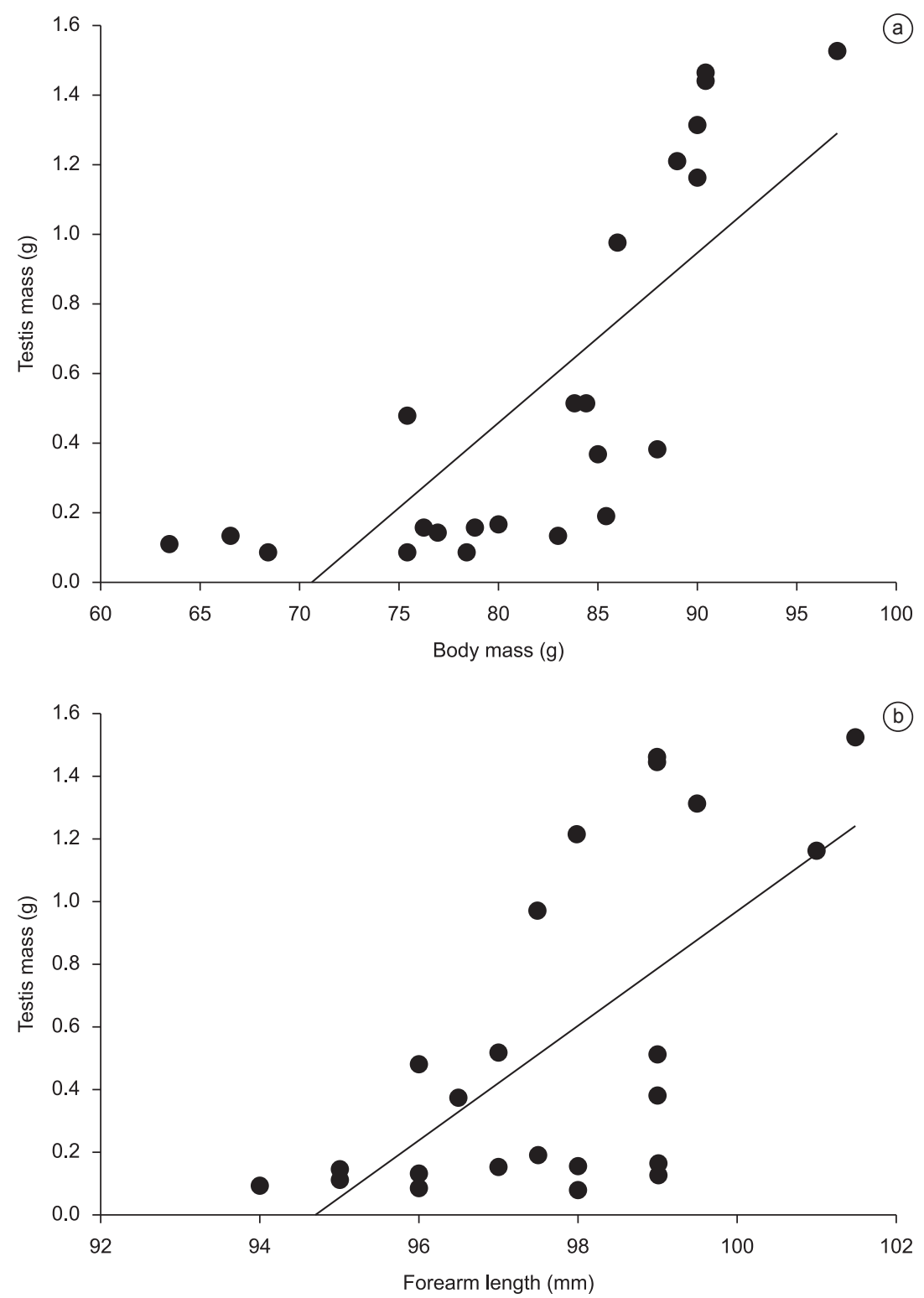

Figure 5. Testis mass correlated with (a) body mass $(r=0.774 ; p<0.001)$ and (b) forearm length $(r=0.643 ; p<0.001)$ in $N$. leporinus males ( $\mathrm{n}=23)$ from a mangrove area in southern Brazil.

Figura 5. Massa do testículo correlacionada com (a) massa corporal $(r=0.774 ; p<0.001)$ e (b) comprimento do antebraço $(r=0.643 ; p<0.001)$ em machos de $N$. leporinus $(\mathrm{n}=23)$ em uma área de manguezal no sul do Brasil.

that indicates adolescence (sexual maturity) in this species. Thus, the correlation graphs (Figure 5) indicate the existence of a size threshold at which males may undergo sexual maturity and become suitable for mating. The size range indicated by our data is $97.5 \mathrm{~mm}$ for forearm length and $85 \mathrm{~g}$ for body weight. This seems reasonable, as there are no seasonal environmental restrictions, such as food resources availability or a rigorous winter, requiring animals to concentrate their mating or sexual maturity in a single period of the year.

In insectivorous vespertilionid bats, which hibernate during the winter in temperate regions, an increase in testis mass and spermatogenic activity only occurs in spring and summer, when there are favorable conditions for feeding and breeding (Kunz et al. 1998). After this period, there is a regression in testis mass and spermatogenic activity, probably oriented to save energy and ensure survival under unfavorable conditions, such low temperatures and a lack of food sources (Entwistle et al. 1998).
Many species of tropical Phyllostomidae synchronize mating and birth with the rainy season, when there is a greater availability of fruit in the environment (Chaverri \& Kunz 2006). For Artibeus lituratus, Reis (1989) and Duarte \& Talamoni (2010) report that births occur throughout the rainy season, with peaks and the beginning and end of the season, accompanied by synchrony with the greater supply of vegetal food sources. In a previous study on the diet of the greater bulldog bat in Guaratuba Bay, Bordignon (2006b) reported that the most frequently consumed species of fish was the Brazilian silverside (Atherinella brasiliensis), which is available throughout the year. Thus, diet is not a limiting factor for the mating period of this species.

The absence of restrictive environmental factors and the polygenic social system in $N$. leporinus, in which the dominant males must be ready to copulate with females ovulating at different times of the year in the harem, may explain the absence of regression in spermatogenic activity in the males of this species. This hypothesis 


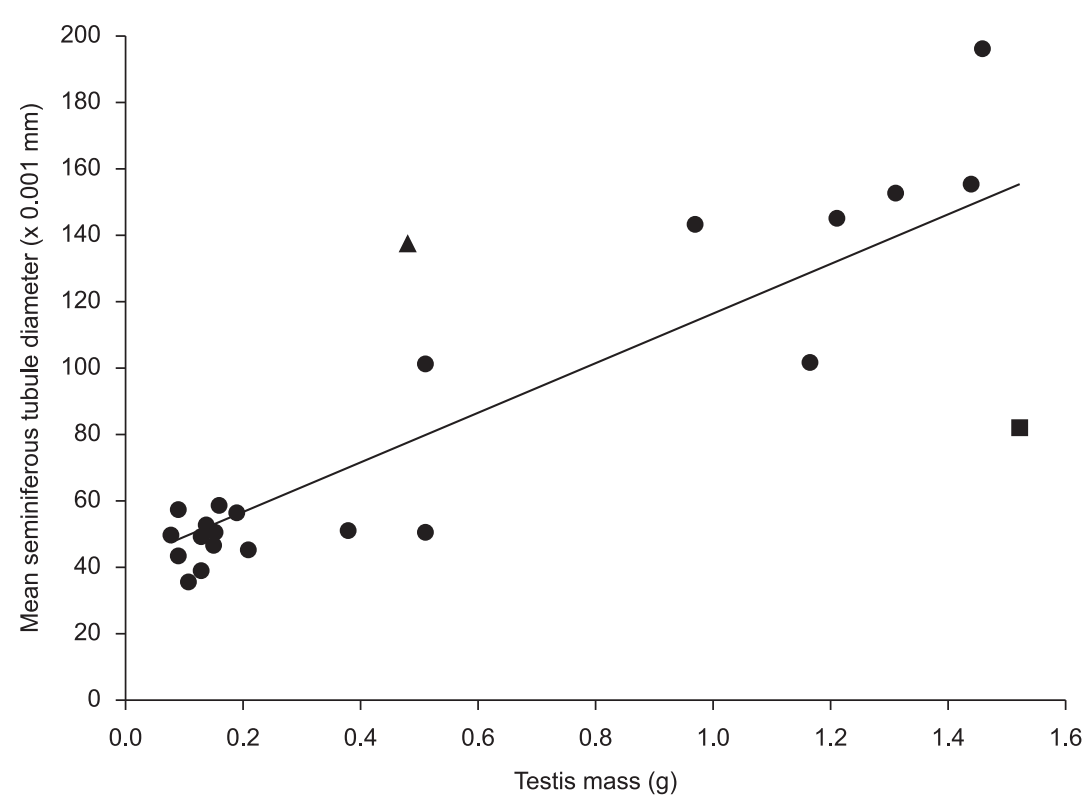

Figure 6. Mean seminiferous tubule diameter $(\mu \mathrm{m})$ correlated with testis mass $(r=0.833 ; p<0.001)$ in $N$. leporinus males $(\mathrm{n}=23)$ from a mangrove area in southern Brazil. The solid square represents a senescent adult male without spermatogenic activity and the solid triangle a young male with testes in maturation. Figura 6. Diâmetro médio dos túbulos seminíferos $(\mu \mathrm{m})$ correlacionado com a massa dos testículos $(r=0.833 ; p<0.001)$ em machos de $N$. leporinus $(\mathrm{n}=23)$ em uma área de manguezal no sul do Brasil. O quadrado sólido representa um macho adulto sem atividade espermatogênica e o triângulo sólido um macho jovem com os testículos em maturação.

is supported by the histological and capture data, as adult males exhibiting spermatogenic activity were recorded in the majority of months. Except for the months January, March and April in all other months were captured males with well developed testes and scrotum.

Another fact that makes us think about the lack of regression of the testes in this species is a male that was captured with large testes (1.52 g), large body mass (97 g) and long forearm length (101.5 mm) exhibited seminiferous tubules with a small diameter $(82.4 \mu \mathrm{m})$ and absence of spermatozoids, thereby suggesting that this male was undergoing an ageing process or andropause.

Recently, Silva et al. (2010) studied this species in captivity. They observed copulations during all months of the year. Though under artificial conditions, these observations corroborate our data, because in our study, all males captured throughout the year showed no decrease in the mass of the testis (testicular regression). Therefore, further long-term histological studies on the copulating behavior of $N$. leporinus in other regions of Brazil are necessary in order to clarify such contradictory data.

\section{Acknowledgements}

We are grateful to the board of directors of the Caiobá Yacht Club for help in the fieldwork and to the "Boticário de Proteção à Natureza" Foundation and UFPR/CAPES/CNPq for logistical and financial support. We also thank two anonymous reviewers for providing helpful comments on the manuscript and valuable references.

\section{References}

BEÇAK, W. \& PAULLETE, J. 1976. Técnicas de Citologia e Histologia. Livros Técnicos, Rio de Janeiro, 189p.

BORDIGNON, MO. \& FRANÇA, AO. 2002. Fish consumption by Noctilio leporinus (Linnaeus, 1758) in Guaratuba Bay, Southern Brazil. Chirop. Neotr. 8(1):148-150.
BORDIGNON, MO. \& FRANÇA, AO. 2004. Variações na coloração da pelagem do morcego-pescador Noctilio leporinus (L., 1758) (Mammalia, Chiroptera). Rev. Bras. Zooci. 6(2):181-189.

BORDIGNON, MO. 2006a. Padrão de atividade e comportamento de forrageamento do morcego-pescador Noctilio leporinus (Linnaeus) (Chiroptera, Noctilionidae) na Baía de Guaratuba, Paraná, Brasil. Rev. Bras. Zool. 23(1):50-57. http://dx.doi.org/10.1590/S010181752006000100003

BORDIGNON, MO. 2006b. Diet of the fishing bat Noctilio leporinus (Linnaeus) (Mammalia, Chiroptera) in a mangrove area of southern Brazil. Rev. Bras. Zool. 23(1):256-260. http://dx.doi.org/10.1590/S010181752006000100019

BROOKE, AP. 1997. Social organization and foraging behaviour of the fishing bat, Noctilio leporinus (Chiroptera: Noctilionidae). Ethol. 103(5):421-436.

CHAVERRI, G. \& KUNZ, TH. 2006. Reproductive biology and post natal development in the tent-making bat Artibeus watsoni (Chiroptera, Phyllostomidae). J. Zool. 270(4):650-656. http://dx.doi.org/10.1111/ j.1469-7998.2006.00171.x

CHAVES, PTC. 1995. Atividade reprodutiva de Bairdiella ronchus (Cuvier) (Pisces, Sciaenidae) na Baía de Guaratuba, Paraná, Brasil. Rev. Bras. Zool. 12(4):75-766.

CHAVES, PTC. \& VENDEL, AL. 1997. Reprodução de Stellifer rastrifer (Jordan) (Teleostei, Sciaenidae) na Baía de Guaratuba, Paraná, Brasil. Rev. Bras. Zool. 14(1):81-89. http://dx.doi.org/10.1590/S010181751997000100008

DUARTE, APG. \& TALAMONI, SA. 2010. Reproduction of the large fruiteating bat Artibeus lituratus (Chiroptera: Phyllostomidae) in a Brazilian Atlantic forest. Mamm. Biol. 75(4):320-325. http://dx.doi.org/10.1016/j. mambio.2009.04.004

ENTWISTLE, AC., RACEY, PA. \& SPEAKMAN, JR. 1998. The reproductive cycle and determination of sexual maturity in male brown long-eared bats, Plecotus auritus (Chiroptera: Vespertilionidae). J. Zool. 244(1):63-70. http://dx.doi.org/10.1111/j.1469-7998.1998.tb00007.x 
ESBÉRARD, CEL. \& BERGALLO, H. 2004. Aspectos sobre a biologia de Tonatia bidens (Spix) no Estado do Rio de Janeiro, sudeste do Brasil (Mammalia, Chiroptera, Phyllostomidae). Rev. Bras. Zool. 21(2):253259. http://dx.doi.org/10.1590/S0101-81752004000200014

FELDHAMER, GA., DRICKAMER, LC., VESSEY, SH. \& MERRITT, JF. 1999. Mammalogy: adaptation, diversity, and ecology. WCB, McGraw-Hill, New York.

GANNON, WL. \& SIKES, RS. 2007. Guidelines of the American Society of Mammalogists for the use of wild mammals in research. J. Mamm. 88(3):809-823. http://dx.doi.org/10.1644/06-MAMM-F-185R1.1

HERNANDEZ, CS., TAPIA, CBC., GARDUNO, AN., CORONA, EC. \& HIDALGO, MAG. 1985. Notes on distribuition and reproduction of bats from coastal regions of Michoacan, Mexico. J. Mamm. 66(3):549-553. http://dx.doi.org/10.2307/1380932

KOOPMAN, KF. 1982. Biogeography of the bats of South America. In Mares MA., Genoways HM., editors. Mammalian Biology in South America. Linesville (PA): Pymatuning Lab. Ecol. Esp. Publ. 6:273-302.

KUNZ, TH., WRAZEN, JA. \& BURNETT, CD. 1998. Changes in body mass and body composition in prehibernating little brown bats (Myotis lucifugus). Ecoscience 5(1):8-17.

MARQUES, RV. \& PACHECO, SM. 1999. Comportamento de cópula de Noctilio leporinus (Linnaeus, 1758) (Mammalia, Chiroptera, Noctilionidae). Comum. Mus. Ciênc. Tec. PUCRS 12(1):193-200.

NOWAK, RM. 1994. Walker's Bats of the World. The Johns Hopkins University Press, London, 287p.

ORTÊNCIO FILHO, H., REIS, NR., PINTO, D. \& VIEIRA, DC. 2007. Aspectos reprodutivos de Artibeus lituratus (Phyllostomidae) em fragmentos florestais na região de Porto Rico, Paraná, Brasil. Chirop. Neotr. 13(2):313-318.
PARREIRA, GG. \& CARDOSO, FM. 1991. Reproductive biology of males of Bolomys lasiurus Lund, 1841 (Rodentia, Cricetidae). I: Spermatogenesis morphology and epithelium seminiferous cycle. Rev. Bras. Biol. 51(3):639-646.

RACEY, PA. 1974. The reproductive cycle in male noctule bats, Nyctalus noctula. J. Reprod. Fertil. 41(1):169-182. http://dx.doi. org/10.1530/jrf.0.0410169

REIS, SF. 1989. Reproductive biology of Artibeus lituratus (Olfers, 1818) (Chiroptera: Phyllostomidae). Rev. Bras. Biol. 49(2):369-372. PMid:2608944.

ROSE, RW., NEVISON, CM. \& DIXSON, AF. 1997. Testes weight, body weight and mating systems in marsupials and monotremes. J. Zool. 243(3):523-531. http://dx.doi.org/10.1111/j.1469-7998.1997. tb02798.x

SCHNITZLER, HU., KALKO, EKV., KAIPF, I. \& GRINNELL, AD. 1994. Fishing and echolocation behavior of the greater bulldog bat, Noctilio leporinus, in the field. Behav. Ecol. Sociobiol. 35(5):327-345. http://dx.doi.org/10.1007/BF00184422

SILVA, AS., PEREIRA, A. \& ESBÉRARD, CEL. 2010. Reprodução de Noctilio leporinus em cativeiro. Chirop. Neotr. 16(1):568-573.

TAMSITT, JR. \& VALDIVIESO, D. 1963. Reproductive cycle of the big fruit-eating bat, Artibeus lituratus Olfers. Nature 198:104. http://dx.doi. org/10.1038/198104a0

WILLIG, MR. 1985. Reproductive patterns of bats from caatingas and cerrado biomes in northeast Brazil. J. Mamm. 66(4):668-681. http://dx.doi. org $/ 10.2307 / 1380793$

ZORTÉA, M. \& AGUIAR, LMS. 2001. Foraging behavior of the fishing bat Noctilio leporinus (Noctilionidae). Chirop. Neotr. 7(1-2):140-142.

Received 30/08/2012

Revised 25/10/2012

Accepted 29/10/2012 